I. CHRZĄŚCIK ${ }^{1}$, A. MARCINIUK-KLUSKA ${ }^{2}$, M. KLUSKA ${ }^{1}$

${ }^{1}$ IC AP Siedlce

${ }^{2}$ IZiM AP Siedlce

\title{
Ekoinnowacje a rozwój zrównoważony
}

\section{Wprowadzenie}

Rozwój zrównoważony jest hasłem używanym przez różne urzędy, organizacje, rządy i autorytety na całym świecie. Obecnie dostępne są liczne publikacje, badania socjologiczne, debaty parlamentarne, tematy konferencji organizowanych przez Unię Europejską i Narody Zjednoczone dotyczące zrównoważonego rozwoju [1].

Z koncepcją zrównoważonego rozwoju wiąże się ogromna różnorodność rozwoju na przykład zrównoważona przedsiębiorczość, zrównoważone wykorzystanie ziemi, zrównoważona edukacja, itp. Niektórzy nawet twierdzą, że zrównoważony rozwój może być rozwiązaniem poważnych problemów socjalnych naszych czasów. Może warto się zastanowić, czy możliwe są tak duże zmiany, które pozwolą na stworzenie sytuacji ekologicznej i ekonomicznej stabilności, tym bardziej warto w dobie obecnego kryzysu finansowego w USA i w Europie. Wskazówki dotyczące zrównoważonego rozwoju pojawiają się od wielu lat. Już w 1972 roku Meadows uznał, iż sytuacja światowej równowagi powinna być tak zaprojektowana, aby spełnić potrzeby materialne każdej osoby na Ziemi i dać każdej osobie te same równe szanse na zrealizowanie swoich ludzkich potrzeb $[2,3]$.

Oprócz trudnego do zrealizowania scenariusza został zaproponowany również możliwy i realny obraz przyszłości. Otóż, gospodarka powinna stać się ostrożna w zużywaniu surowców poprzez stymulowanie ponownego używania oraz recykling. Ważnym zagadnieniem powinno być także podjęcie poważnych wysiłków, aby przestawić się na surowce, które są odnawialne. Na przykład poprzez używanie odnawialnych surowców, typu papier i woda, zamiast plastików (wytwarzanych z ropy naftowej, która jest surowcem nieodnawialnym).

W 1980 roku została opublikowana Światowa Strategia Oszczędzania, polegająca na oszczędzaniu żywych zasobów dla zrównoważonego rozwoju. Raport ten wyjaśniał i podkreślał, że zakłócenie procesów i funkcji ekologicznych oraz utrata zasobów naturalnych, jak lasy i pola uprawne, szczególnie w krajach spoza kultury zachodniej stanowią barierę w zrównoważonym rozwoju. W takiej strategii po raz pierwszy zdefiniowano zrównoważony rozwój w określeniu między- 
narodowym. Aby rozwój był zrównoważony to należy brać pod uwagę czynniki socjalne i ekologiczne, żyjące i nieżyjące zasoby, jak również czynniki długookresowe i krótkookresowe. Koncepcja zrównoważonego rozwoju była i jest często łączona z Komisją Brundtland, czyli Światową Komisją Środowiska i Rozwoju (The World Commission on Environment and Development) powstałą w 1983 roku. Komisja ta w 1987 roku opublikowała dokument - Nasza wspólna przyszłość. W dokumencie tym zwrócono uwagę na bardzo ważne zagadnienie, jakim jest nierówność. Stwierdzono, że nierówność jest największym problemem środowiskowym na świecie i stanowi fundamentalny problem rozwoju [4]. Zatem można powiedzieć, że nie ma ekologii bez równości i nie ma równości bez ekologii.

Z rozwojem zrównoważonym związana jest wszelka innowacyjność, a szczególnie innowacje ekologiczne, dotyczące zmian w technologii, strukturze organizacyjnej i zarządzaniu: zakładem, przedsiębiorstwem, czy gospodarką kraju. Klasyfikację innowacji ekologicznych można przeprowadzić z punktu widzenia różnych kryteriów. Jako jedno z kryteriów podziału innowacji ekologicznych można przyjąć sferę działalności przedsiębiorstwa. W związku z tym wyróżniamy innowacje ekologiczne zawarte w: produkcie lub usługach, procesie produkcyjnym, zarządzaniu i organizacji.

Innowacje ekologiczne w produkcie lub usługach zmniejszają lub eliminują zanieczyszczenie środowiska. Konieczne są działania ekologiczne w całym asortymencie produkcji. Każda nowa propozycja w zakresie projektowania i wdrażania nowego wyrobu wymaga weryfikacji z punktu widzenia ochrony środowiska naturalnego.

Istotnym obszarem innowacji ekologicznych jest proces produkcyjny, rozumiany szeroko, począwszy od zaopatrzenia materiałowego aż do zbytu wyrobów. Należy poddać analizie pod kątem oddziaływania na środowisko naturalne każdą operację procesu produkcyjnego. Optymalizacja procesu technologicznego z punktu widzenia ilości i jakości odpadów stanowi klasyczne zadanie rozwojowe. Nowe wymogi w tej dziedzinie, które weszły wraz ze wstąpieniem Polski do Unii Europejskiej sprawiły wzrost innowacji ekologicznych. Pojawiło się stwierdzenie, że zakład, przedsiębiorstwo, które spełni je lepiej i szybciej, bardziej umocni swoją pozycję na rynku. Obecnie wiadome jest, że taniej i łatwiej jest stosować nowe technologie, niż poszukiwać sposobów redukcji zanieczyszczeń powstałych na skutek stosowania przestarzałych technologii [5].

\section{Ekoinnowacyjność w Polsce i Unii Europejskiej}

Większość inwestycji podejmowanych przez firmy w Polsce to inwestycje w sprzęt i infrastrukturę, czyli głównie budynki i maszyny (łącznie ponad 80\% nakładów). Tylko 7,5\% inwestycji dotyczy finansowania badań, mających na celu opracowanie nowej technologii, ekotechnologii lub ekoproduktu. Tymczasem, innowacje są niezbędne, aby nasza gospodarka mogła się rozwijać w przyszłości [6]. 
Największe polskie firmy, czyli takie, których roczny zysk netto wynosi ok. dwóch miliardów złotych, wydają rocznie na badania ok. $10 \mathrm{mln}$. Kwota ta jest niewątpliwie bardzo mała. Chcąc trwać i rozwijać się, firmy powinny zmienić swoje podejście do innowacji, a przede wszystkim do ekoinnowacji prowadzących w kierunku zrównoważonego rozwoju. Zwykle polskie firmy nie chcą ryzykować i tworzyć własnych technologii. Innowacjom nie sprzyja także rynek konsumencki. Z tego wynika, że współpraca między biznesem, a nauką należy w Polsce prawie do rzadkości. Zwykle przedsiębiorcy obawiają się ryzyka związanego z finansowaniem innowacji. Jako główne czynniki ryzyka wymieniają koszt opracowania i wdrażania nowatorskich rozwiązań oraz fakt, że na innowacyjne technologie ekologiczne nie ma w Polsce dużego popytu, zatem nie ma pewności, że inwestycja w stworzenie nowego produktu będzie opłacalna.

Obecnie jeszcze w Polsce istnieje taka tradycja, że klient, który przychodzi do sklepu kupić jakiś produkt i ma do wyboru droższy innowacyjny albo tradycyjny, ale tańszy o kilka procent to wybierze zazwyczaj ten tańszy. Potwierdza to fakt, że, na razie w Polsce nie ma rynku sprzyjającego ekoinnowacjom. Firmy nie czują potrzeby rozwijania nowych technologii. Ponieważ inni tego nie robią, więc nie ma pod tym względem konkurencji, a zatem nie istnieje taka potrzeba i konieczność. Polskie firmy preferują sprowadzanie znanych rozwiązań z innych krajów, bo to nie wiąże się z takim ryzykiem. Przedsiębiorcy wolą utrzymywać pozycję na rynku dzięki wysokiej jakości i relatywnie niskiej cenie towarów i usług, niż dzięki ich ekoinnowacyjności.

W Polsce szczególnie przedsiębiorcy potrzebują zachęt i ułatwień, aby częściej podejmować współpracę z naukowcami. Na razie realizowane są od kilku lat pojedyncze tzw. projekty celowe, które polegają na tworzeniu przez naukowców nowych rozwiązań we współpracy z prywatnym przedsiębiorstwem na konkretne zamówienie. Taki projekt może liczyć na wsparcie ze środków publicznych nawet do kilku milionów zł. Do tej pory takich projektów zrealizowano w Polsce ok. 500. Ogromną rolę we współpracy powinien odgrywać rząd, który powinien rozwijać różne ułatwienia i dotacje dla ekoprojektów, w których współpracowaliby naukowcy z przedsiębiorstwami, a powstające technologie zmierzałyby do zrównoważonego rozwoju [7].

Innowacyjność w Polsce jest nadal poniżej średniej w Unii Europejskiej. Z kolei Unia Europejska ma wiele do nadrobienia, by dogonić Stany Zjednoczone w innowacyjności i nakładach na badania i rozwój. Polskę również czeka jeszcze wiele wysiłku, by dociągnąć do średniej unijnej. Unijnymi liderami, których Komisja Europejska stawia na równi z Japonią i Szwajcarią, są Niemcy, Dania, Szwecja i Finlandia. Polska jest w grupie krajów, które są znacznie poniżej unijnej średniej i muszą nadrobić dystans dzielący je od czołówki. Informacje te wynikają z raportu KE dotyczącego zakresu innowacyjności. Raport ten opracowano na podstawie licznych kryteriów, począwszy od poziomu wykształcenia społe- 
czeństwa, przez nakłady na technologie informatyczne i telekomunikacyjne oraz inwestycje w badania i rozwój, po liczbę zgłaszanych patentów. By znaleźć się w czołówce, należy osiągać dobre wyniki we wszystkich dziedzinach [8].

Polska jest powyżej unijnej średniej tylko pod względem wykształcenia wśród młodzieży, jest ono wyraźnie wyższe niż w pozostałych krajach UE. Prawie 90\% polskich dwudziestolatków skończyło szkołę średnią (w UE zaledwie 77\%). Odsetek osób przedwcześnie kończących edukację wynosi w Polsce $5,5 \%$, a w UE - ponad 15\%. W pozostałych dziedzinach jest znacznie gorzej. KE wytyka Polsce zwłaszcza nikłą liczbę nowych wynalazków zgłaszanych do Europejskiego Urzędu Patentowego, niewielkie inwestycje firm w badania i rozwój, niski poziom eksportu zaawansowanego technologicznie oraz jedną z najgorszych w Europie sieć dostępu do szerokopasmowego Internetu [9].

W 2006 roku UE uruchomiła 10-punktowy plan innowacji, w którym nawoływała do podjęcia pilnych działań na poziomie regionalnym, krajowym i europejskim. Zawartość planu opierała się na wytycznych byłego premiera Finlandii Esko Aho i stanowiła okrojoną wersję raportu „Tworzenie innowacyjnej Europy”, przygotowanego przez grupę ekspertów pod kierownictwem Aho i opublikowanego w styczniu 2006 r. Postulowano, aby Europa stała się społeczeństwem rzeczywiście opartym na wiedzy i przyjaznym innowacjom (ekoinnowacjom), miejscem, gdzie innowacje nie będą napawały niepokojem, ale przyjmowane będą przychylnie, nie będą utrudniane, lecz wspierane i stanowić będą element podstawowych wartości społecznych, działając na korzyść wszystkich obywateli. Zwrócono uwagę, aby nie postrzegać zmian strukturalnych jako zagrożenie, lecz szansę na zwiększenie własnej konkurencyjności [10].

Duże znaczenie Komisja przypisywała tworzeniu tzw. wiodących rynków przyjaznych innowacjom, opartych na łączeniu innowacji i odpowiednich instrumentów politycznych w celu wyeliminowania przeszkód w opracowywaniu i wprowadzaniu na rynek nowych produktów ekoinnowacyjnych oraz stymulowaniu na nie popytu. Jako cel nadrzędny stanowiący interes publiczny uznano: ochronę środowiska, e-zdrowie, leki, energetykę, transport i logistykę, bezpieczeństwo i treści cyfrowe.

Innowacyjność jest ściśle związana $\mathrm{z}$ badaniami naukowymi. W sferze badań Komisja Europejska ciągle nawołuje naukowców do większej mobilności, zarówno między krajami, jak i sektorami oraz do nawiązania bliższych kontaktów między środowiskiem badawczym a przemysłem. Jeśli fundamentalna polityka UE nie obejmuje szkolnictwa, wówczas innowacje nie otrzymują należnego wsparcia. Według wspomnianego planu, kluczowe kompetencje niezbędne do życia i pracy w nowoczesnym społeczeństwie zorientowanym na ekoinnowacje prowadzące do zrównoważonego rozwoju, obejmują wiedzę z zakresu przedsiębiorczości, umiejętność czytania i pisania, kwalifikacje naukowe i matematyczne, znajomość języków obcych, zdolności do samodzielnego uczenia się, kompeten- 
cje społeczne i kulturowe oraz znajomość technik cyfrowych. Oprócz wspomnianych wyżej zagadnień należących do 10 punktowego planu należą m.in.:

- stworzenie jednolitego rynku pracy dla naukowców,

- wzmocnienie kontaktów między naukowcami a przemysłem,

- wspieranie regionalnych innowacji za pomocą nowych programów polityki spójności,

- zreformowanie zasad udzielania pomocy państwowej na innowacje oraz opracowanie wyczerpujących wskazówek dotyczących zachęt podatkowych,

- modyfikacja opłat $\mathrm{z}$ tytułu praw autorskich $\mathrm{w}$ odniesieniu do produktów i usług cyfrowych,

- stymulowanie innowacji za pomocą zamówień publicznych i prywatnych,

- stworzenie systemów kształcenia przyjaznych innowacjom.

Innowacje i zrównoważony rozwój mają zasadnicze znaczenie dla wzrostu gospodarczego. Zrównoważony rozwój od dawna był jednym $\mathrm{z}$ europejskich priorytetów. Obecnie nabrał on nowego znaczenia w świetle kryzysu związanego ze zmianami klimatu. Jednak nadal stanowi wielkie wyzwanie dla miast i regionów UE. Coraz częściej organizowane są imprezy stanowiące dla regionów i miast okazję do wymiany doświadczeń w zakresie swoich największych sukcesów i najlepszych pomysłów na pobudzenie wzrostu gospodarczego i zwiększenie liczby miejsc pracy. Przykład takiej działalności stanowią m.in. parki technologiczne, innowacyjne systemy rewitalizacji obszarów miejskich czy bardzo szybkie połączenia transportowe. Wydarzenia takie są doskonałą okazją dla miast i regionów do pokazania tego, w jaki sposób wykorzystują środki z Europejskiego Funduszu Rozwoju Regionalnego, którego budżet w okresie 2007-2013 wyniesie 347 mld euro. Zamożniejsze regiony zwykle wydają więcej na badania i rozwój $\mathrm{w}$ porównaniu $\mathrm{z}$ mniej zamożnymi regionami, tym samym bogacą się szybciej i jeszcze bardziej zwiększają nierówności [7].

Z przybliżonych powyżej założeń planu przedstawionego w 2006 roku niestety znaczna część jest jeszcze do wykonania. Unia Europejska nadal pozostaje w tyle za Stanami Zjednoczonymi. O przepaści dzielącej UE z USA w dziedzinie innowacyjności decyduje - zdaniem KE dostępność kapitału wysokiego ryzyka, o który o wiele łatwiej w Stanach Zjednoczonych, wysoki odsetek Amerykanów z wyższym wykształceniem, choć niekoniecznie uniwersyteckim i wysoka liczba nowych wynalazków w USA, czego rezultatem są zgłaszane patenty. Obecnie obraz ten może delikatnie się zmienić na korzyść UE ze względu na ogromny kryzys finansowy, przede wszystkim w USA.

Innowacje zależą przede wszystkim od prawidłowego otoczenia rynkowego, które sprzyja innowacyjności. Aby stworzyć otoczenie rynkowe sprzyjające innowacyjności, należy wyraźnie określić, jakie działania polityczne trzeba wdrożyć, aby UE stała się bardziej przyjazna innowacjom. Jeżeli prawidłowo zostanie ukształtowane otoczenie rynkowe, w ślad za tym pojawią się pożądane wskaźniki 
innowacyjności. Wzrost gospodarczy UE i jej konkurencyjność w stosunku do reszty świata zależą przede wszystkim od innowacji ekologicznych. Innowacjom w UE poświęca się wiele uwagi, ale może należałoby wyjść poza sferę deklaracji. Innowacyjność w UE jest raczej na dobrym poziomie, istnieje natomiast prawdziwy problem z przełożeniem innowacji na produkty, przedsiębiorstwa klasy światowej, udział w rynku światowym i atrakcyjne miejsca pracy.

\section{Ocena Polskiego Systemu Innowacji przez KE}

Komisja Europejska publikuje raporty (European Trend Chart on Innovation) poświecone poszczególnym członkom Unii Europejskiej. W przypadku Polski dokument ten zawierał analizę obecnego systemu innowacji, uwzględniając podstawowe kwestie dotyczące: podmiotów odpowiedzialnych za kształtowanie polityki, aspekty finansowe oraz wdrażanie proponowanych rozwiązań, a także wyniki poszczególnych wskaźników tzw. European Innovation Scoreboard [11].

$\mathrm{W}$ ramach analizy krajowego systemu innowacji dobrze oceniono sam proces tworzenia strategicznych dokumentów kształtujących politykę innowacyjną państwa. Wskazano, iż systematycznie ukazują się kolejne programy rządowe, czerpiące $\mathrm{z}$ doświadczeń poprzednich programów, jak i doświadczeń innych krajów, prowadzone są konsultacje, dzięki czemu przygotowane dokumenty w części diagnostycznej i proponowanych rozwiązań są na odpowiednio wysokim poziomie.

Jednocześnie Komisja Europejska zarzuciła Polsce całkowity brak koordynatora na poziomie rządowym. Brak jest jasnej odpowiedzi, kto w Polsce odpowiada bezpośrednio za politykę innowacyjną (część kompetencji jest w Ministerstwie Gospodarki, cześć w Ministerstwie Nauki i Szkolnictwa Wyższego). Brak jest również tzw. kultury ewaluacyjnej, która przyczynia się do lepszego planowania programów, które powinny zawierać odpowiednie mierniki, pozwalające na systematyczną ewaluację, czy dany program jest wdrażany i czy osiąga zamierzone cele. Odnotowano, iż sprawy finansowe skupiają się jedynie na analizie funduszy strukturalnych oraz sprawach podatkowych.

Pozytywnie wypadł według KE dobór instrumentów stworzonych w ramach Programów Operacyjnych, choć są pewne mankamenty, na które zwrócono uwagę. Dotyczą one m. in. wprowadzenia ulg podatkowych dla przedsiębiorców prowadzących prace badawczo-rozwojowe. W tym przypadku zmiany już nastąpiły, gdyż obecnie według nowej ustawy, przedsiębiorca może odliczyć koszty prac badawczo-rozwojowych bez względu na wynik zakończonych prac, co wcześniej nie było możliwe.

Wdrażanie polityki innowacyjnej odbywa się zarówno na poziome krajowym, jak i regionalnym. Główną słabością Krajowego Systemu Innowacji w Polsce jest po prostu brak wspomnianego wyżej koordynatora, który byłby odpowiedzialny za wdrażanie programów dotyczących innowacyjności. Kuleje również współ- 
praca pomiędzy uczelniami, jednostkami badawczymi a przemysłem. Reformy przeprowadzane są bardzo powoli, a uczelnie wyższe mają za mały wpływ na kształtowanie polityki innowacyjnej państwa.

European Innovation Scoreboard wykorzystuje 25 wskaźników podzielonych na 5 kategorii dla obrazowania zdolności innowacyjnych danego kraju. Są to: zasoby ludzkie, tworzenie wiedzy, przepływ wiedzy, finansowanie innowacji oraz wskaźniki makroekonomiczne.

Polska obecnie najwyższe miejsca zajmuje w kategoriach: wydatki na technologie informacyjno-komunikacyjne (8 miejsce) oraz liczbie osób mogących pracować w sektorze badawczo-rozwojowym (11 miejsce). Najgorzej wypadamy w dziedzinach patentów wysokich technologii (ostatnie miejsce) oraz wydatkach sektora prywatnego na badania i rozwój (24 miejsce) [12].

Omawiany przez autorów niniejszego artykułu dokument przedstawia konkretnie sześć wyzwań, które mogą znacząco podnieść jakość Krajowego Systemu Innowacji w Polsce. Są to:

- promocja klastrów oraz innych form kooperacji między przedsiębiorcami,

- stworzenie przyjaznego środowiska dla ekoinnowacyjnych działań przedsiębiorców,

- stworzenie mechanizmu koordynacji działań głównych podmiotów odpowiedzialnych za sprawy związane $\mathrm{z}$ innowacjami, mając na uwadze również osoby regionalne, które są odpowiedzialne za regionalne strategie innowacji,

- wprowadzenie zmian umożliwiających łatwiejszy dostęp do dodatkowych źródeł finansowania prac badawczo rozwojowych w sektorze prywatnym oraz reforma rozdrobnionego publicznego sektora naukowego,

- udoskonalenie jakości zasobów ludzkich i wzrost liczby młodych ludzi, którzy wejdą na ścieżkę kariery związaną z nauką, inżynierią i technologią,

- wzmocnienie współpracy pomiędzy sektorem badawczym a przemysłem i ułatwienie transferu technologii.

\section{Podsumowanie}

Innowacje ekologiczne oraz technologie stosowane w ochronie środowiska stanowią poważny bodziec dla wzrostu ekonomicznego oraz przyczyniają się do realizowania celów związanych z zatrudnieniem. Obecnie ekologiczne sektory przemysłowe UE stanowią ponad 1/3 rynku światowego. Również w Polsce sektory te odgrywają coraz większe znaczenie. Sytuacja taka sprzyja zrównoważonemu rozwojowi.

Polityka ochrony środowiska i zrównoważonego rozwoju w UE polega na podziale odpowiedzialności. Konieczne jest, zatem równoległe zaangażowanie wszystkich państw UE i wprowadzanie w coraz większym stopniu zasad zrównoważonego rozwoju. Zintensyfikowanie realizacji takiej polityki wzmoże działania 
w dziedzinie ochrony środowiska, co będzie pozytywnym impulsem w kierunku zrównoważonego rozwoju.

Zagrożenia dla zasobów naturalnych występują globalnie, tak jak zmiana klimatu oraz utrata zróżnicowania biologicznego. UE zobowiązana jest wskazywać drogę zarówno wewnętrzną, jak i zewnętrzną poprzez wspieranie partnerów międzynarodowych. Obywatele europejscy dbają o środowisko i są zdania, że jest to dziedzina, w której UE przyczynia się i powinna nadal przyczyniać się do ochrony środowiska, zarówno na swoim terenie, jak i na całym świecie. Ochronę środowiska należy zawsze łączyć ze wzrostem ekonomicznym, integracją społeczną oraz zrównoważonym rozwojem.

Czasami innowacje można postrzegać jako zagrożenie. Zarówno w Polsce, jak i w UE istnieje potrzeba innowacji, szczególnie ekoinnowacji. Zakres potrzeb innowacyjnych jest szerszy i znacznie wykracza poza ekologię. Nie zawsze muszą to być innowacje technologiczne. Należy raczej wypracować i edukować taki sposób myślenia, który nie pozwoli nam zachować obecnego stanu rzeczy, lecz zachęci do ulepszenia produktu, metod produkcji, projektowania, sprzedaży, a tym samym do zrównoważonego rozwoju. Upowszechnienie takiego myślenia stanowi duże wyzwanie. Coraz więcej osób angażuje się w strategie dotyczące innowacji. Wszystkie Fundusze Strukturalne, fundusze regionalne uczyniły z innowacji jedno z głównych kryteriów prowadzonych inwestycji.

Wielokrotnie największym źródłem innowacji są nowi i wykształceni pracownicy. Ich wiedza i umiejętności znacznie zwiększają zdolność do podejmowania nowych inicjatyw. Dlatego, tak ważne jest wspieranie działań umożliwiających wymianę informacji i doświadczeń na szczeblu europejskim, czy światowym.

Osiągnięcie zrównoważonego rozwoju jest bardzo trudne, ale możliwe pod warunkiem wspólnego wysiłku i zrozumienia całego społeczeństwa. Niektóre efekty wprowadzania innowacji ekologicznych powinny być zatem zauważalne z roku na rok. Inne zaś będą widoczne dopiero po kilkudziesięciu latach, np. poprawa zdrowia publicznego.

\section{Bibliografia}

[1] De Knecht D., Zrównoważony rozwój, w: Innowacje, 2008, 25, 1-2.

[2] Meadows D. H., Meadows D., Randers J., Behrens III W. W., Granice wzrostu, PWE, Warszawa 1973.

[3] Ciążela H., Antycypacja idei rozwoju trwałego i zrównoważonego w koncepcji nowego humanizmu Aurelio Peccei, Problemy Ekorozwoju, 2007, 2, 1, 59-67.

[4] World Commission on Environment and Development, Our Common Future, Oxford University Press 1987.

[5] Janasz W., Kozıo£ K., Determinanty działalności innowacyjnej przedsiębiorstw, PWE, Warszawa 2007.

[6] MarCINIUK-KLUSKa A., KlusKa M., Ekologia i technika a rozwój innowacji, Ekologia i Technika, 2008, XVI, No 1, 23-26. 
[7] Marciniuk-Kluska A., Chrząścik I., Kluska M., Prognoza wydatków inwestycyjnych w Polsce na innowacje ekologiczne w latach 2007-2013, Ekologia i Technika, 2008, XVI, No 2, 47-51.

[8] Zacher L.W., Trwały rozwój - utopia czy realna możliwość?, Problemy Ekorozwoju, 2008, 3, No 2, 63-68.

[9] ZACHER L.W., Edukacyjne i doradcze aspekty ekologicznych wyzwań Unii Europejskiej wobec przedsiębiorczości, w: K. KucıŃsKi (red.), Przedsiębiorstwa i gospodarki po wstąieniu do Unii Europejskiej, SGH, Warszawa 2005.

${ }^{[10]}$ ZACher L.W., Bezpieczeństwo ekologiczne i społeczne, w: M. Bożek, M. Troszyński (red.), Europa - kontynent ryzyka?, Wyd. AON, Warszawa 2007.

${ }^{[11]} \mathrm{http}: / /$ ec.europa.eu/enterprise/innovation/index_en.htm.

${ }^{[12]}$ Marciniuk-KLusKa A., KlusKa M., Finansowanie innowacji w województwie mazowieckim w latach 2007-2013, Zeszyty Naukowe Uniwersytetu Szczecińskiego, 2008, 501, 261-268.

\title{
Ecoinnovations and sustainable development
}

\begin{abstract}
SUMMARY
This work presents the issues concerning connections between ecoinnovations and sustainable development in Poland and European Union. Innovations and sustainable development are of fundamental importance for the growth in economy. Sustainable development has been one of European priorities for a long time. At present it has acquired new significance in the light of the crisis connected with climate changes and the extensive financial crisis prevailing mainly in the USA and Europe. Still it is a great challenge for EU cities and regions. Also examined were little cooperation between entrepreneurs and people of science in the processes introducing modern technologies and expenditure on innovations.
\end{abstract}

Key words: Ecological innovations, sustainable development 